\title{
Mice with Inactivation of Aryl Hydrocarbon Receptor-Interacting Protein (Aip) Display Complete Penetrance of Pituitary Adenomas with Aberrant ARNT Expression
}

Anniina Raitila, ${ }^{*}$ Heli J. Lehtonen, ${ }^{*}$ Johanna Arola, ${ }^{\dagger}$ Elina Heliövaara, ${ }^{*}$ Manuel Ahlsten, ${ }^{*}$ Marianthi Georgitsi, ${ }^{*}$ Anu Jalanko, ${ }^{\star}$ Anders Paetau, ${ }^{\dagger}$ Lauri A. Aaltonen, ${ }^{*}$ and Auli Karhu*

From the Department of Medical Genetics," Genome-Scale Biology Research Program Biomedicum, University of Helsinki, Helsinki; the Department of Pathology, ${ }^{\dagger}$ The Laboratory of Helsinki University Central Hospital (HUSLAB), Helsinki University Central Hospital and Haartman Institute, University of Helsinki, Helsinki; and the National Institute for Health and Welfare (THL), Public Health Genomics Unit and FIMM, Institute for Molecular Medicine Finland, ${ }^{\ddagger}$ Biomedicum Helsinki, Helsinki, Finland

Mutations in the aryl bydrocarbon receptor-interacting protein (AIP) gene have been shown to predispose to pituitary adenoma predisposition, a condition characterized by growth hormone (GH)-secreting pituitary tumors. To study $A I P$-mediated tumorigenesis, we generated an Aip mouse model. Heterozygous mice developed normally but were prone to pituitary adenomas, in particular to those secreting GH. A complete loss of AIP was detected in these lesions, and full penetrance was reached at the age of 15 months. No excess of any other tumor type was found. Ki-67 analysis indicated that Aip-deficient tumors have higher proliferation rates compared with $\mathrm{Aip}$-proficient tumors, suggesting a more aggressive disease. Similar to human AIP-deficient pituitary adenomas, immunohistochemical studies showed that expression of aryl hydrocarbon receptor nuclear translocator 1 or 2 (ARNT or ARNT2) protein was lost in the mouse tumors, suggesting that mechanisms of $A I P$-related tumorigenesis involve aberrant ARNT function. The $\mathrm{Aip}^{+/-}$mouse appears to be an excellent model for the respective human disease phenotype. This model constitutes a tool to further study AIPassociated pituitary tumorigenesis and may be potentially valuable in efforts to develop therapeutic strategies to treat pituitary adenomas. (Am J Pathol 2010, 177:1969-1976; DOI: 10.2353/ajpath.2010.100138)
Pituitary adenomas are common, benign, monoclonal neoplasms of the anterior pituitary gland. They account for approximately $15 \%$ of intracranial tumors. Approximately two thirds produce pituitary hormones in excess; among these, prolactin (PRL) and growth hormone $(\mathrm{GH})$ oversecreting adenomas are the most common. The significant morbidity associated with these lesions arises from the adverse effects of the hypersecretion, such as acromegaly or gigantism in the case of $\mathrm{GH}$ secreting adenomas, and/or local compressive effects. ${ }^{1}$

Mutations in the aryl hydrocarbon receptor interacting protein $(A I P)$ gene have been identified as an underlying cause in human pituitary adenoma predisposition (OMIM 102200), characterized mainly by GH secreting adenomas (somatotropinomas), although susceptibility to PRL (prolactinomas), adrenocorticotropic hormone (ACTH), and nonsecreting adenomas is also part of the disease phenotype. ${ }^{2-5}$ So far AIP mutations have not been associated with any other tumor types. ${ }^{6-8}$ Typically, pituitary adenoma predisposition patients have a young age at disease onset but do not necessarily display a strong family history of pituitary adenomas. AIP mutation positive tumors seem to be larger and may have a worse response to somatostatin analogs as compared to sporadic tumors. ${ }^{4,5,9}$

Inactivating germline mutations, loss of the normal allele in tumors, as well as recent functional evidence implicate the tumor suppressor role of the AIP gene. 2,5,10 Many of the proteins known to interact with AIP can be linked to tumorigenesis. The best known function of AIP is to stabilize aryl hydrocarbon receptor (AHR) (also known

Supported by Helsinki Biomedical Graduate School, the Academy of Finland (grant 6302352), the Sigrid Jusélius Foundation (grant 4701169), Finnish Cancer Organizations, and the Cancer Society of Finland (grants 4700325 and 4702054).

Accepted for publication June 24, 2010.

Supplemental material for this article can be found on http://ajp. amjpathol.org

Address reprint requests to Auli Karhu, Ph.D., Department of Medical Genetics, Biomedicum Helsinki, P.O. Box 63 (Haartmaninkatu 8), 00014 University of Helsinki, Finland. E-mail: auli.karhu@helsinki.fi. 
A

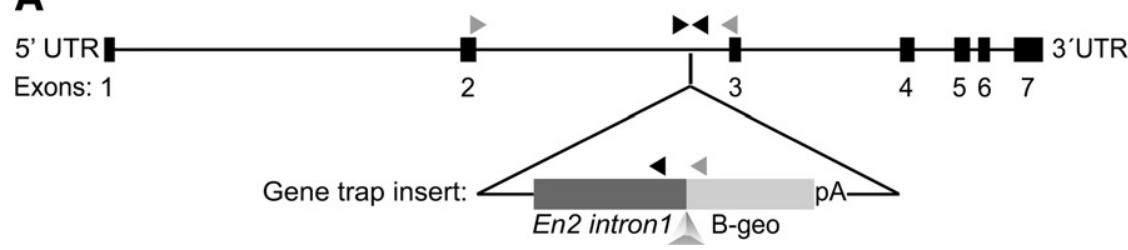

B

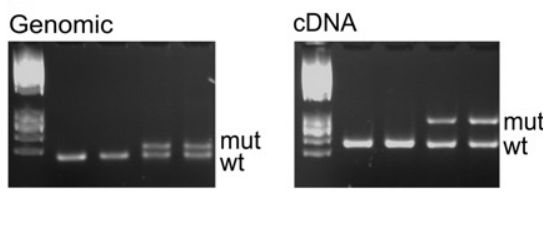

Figure 1. Construct and validation of Aip-deficient mice. A: Genomic structure of Aip (transcript ENSMUST00000117831) and the gene trap vector construct inserted in the intron between exons 2 and 3 . The gray triangle represents the splice acceptor site after mouse En2 intron 1 sequence. B-geo is a fusion gene of $\beta$-galactosidase and neomycin, and $\mathrm{pA}$ is a polyadenylation signal. Black arrowheads designate genomic PCR primers, and gray arrowheads designate cDNA PCR primers used in genotyping. B: Results of genomic and cDNA PCR genotyping with wt (wild-type) and mut (mutant) bands.

as dioxin receptor) in a cytoplasmic chaperone complex together with heat shock protein 90 (HSP90) and p23. The binding of dioxins or dioxin-like chemicals leads to shuttling of AHR to the nucleus, where it forms a complex with the aryl hydrocarbon receptor nuclear translocator 1 [ARNT, also known as hypoxia-inducible factor (HIF)-1 $\beta$ ]. The AHR/ARNT heterodimer regulates the expression of several xenobiotic metabolizing enzymes. ${ }^{11}$ ARNT is also required by $\mathrm{HIF}-1 \alpha$ in the nucleus. ARNT/HIF- $1 \alpha$ heterodimer regulates several genes involved in tumorigenesis under hypoxia, and $\mathrm{HIF}-1 \alpha$ is present in many tumors, contributing to angiogenesis, proliferation, metastasis, and resistance to radiation therapy. ${ }^{12}$ Thus, the ubiquitously expressed ARNT is an essential partner in the physiological response to chemical toxicants and hypoxia. ARNT participates also in the regulation of estrogen receptor signaling. ${ }^{13,14}$ Interestingly, it has been shown that ARNT2, an ARNT homolog, can compensate the lack of ARNT and form a functional complex with HIF-1 $\alpha$ under hypoxia. However, it seems that ARNT2 is not capable of cooperating with AHR in the activation of xenobiotic responsive element-dependent genes. ${ }^{15}$ ARNT2 was initially classified as being expressed in neural tissue and the kidney. ${ }^{16}$ While much is known about the function of ARNT, the expression pattern and dimerization partners of ARNT2 are less clear. Recently, we showed that expression of ARNT is significantly reduced in human AIP-deficient pituitary adenomas, suggesting a link between AIP and AHR/ARNT signaling in pituitary tumorigenesis. ${ }^{10}$ However, further studies are needed to unravel the mechanism by which AIP exerts its tumor suppressive action in the pituitary.

Mouse models have been used to study various aspects of pituitary development, function, and disease. A recently published Aip (Ara9) mouse model revealed that homozygous germline Aip mutations are embryonic lethal and homozygous mutant embryos die due to various cardiovascular malformations. In addition, most mice with reduced Aip expression showed failure of liver vein inclusion resulting in reduced liver size. ${ }^{17,18}$ However, possible tumor predisposition was not approached in either study.

Here we report a novel conventional Aip knockout mouse, which models the tumor susceptibility caused by human AIP germline mutations. We show that $\mathrm{Aip}^{+/-}$ mice are extremely prone to pituitary tumors, in particular $\mathrm{GH}$ secreting adenomas. In addition, we provide evidence that Aip-associated tumors present a more aggressive disease profile and that Aip deficiency in pituitary tumors has a striking effect on the presence of ARNT and ARNT2 proteins, the heterodimerization partners of $\mathrm{HIF}-1 \alpha$. Overall, these results indicate that the Aip mouse model provides an excellent model for the human phenotype and suggest that mechanisms of AIP related tumorigenesis involve aberrant ARNT function.

\section{Materials and Methods}

\section{Ethics Statement}

All of the animal experiments were authorized by the appropriate review committee, and regulations concerning the use of animals in research were adhered to.

\section{Generation of Aip $^{+/-}$Mice}

To generate the Aip mouse model, embryonic stem (ES) cells containing the gene trap vector construct in an intronic region of genomic DNA between Aip exons 2 and 3 (ENSMUST00000117831) were used (BayGenomics, University of California, Davis, CA). ${ }^{19}$ Embryonic Stem (ES) cells were injected into blastocysts, and chimeras were identified. For the generation of congenic mice, inbred mouse strain C57BL/6Rcc was used. Mice were genotyped by multiplex PCR from cDNA and genomic DNA. Total RNA or DNA was extracted from an ear piece using RNeasy mini kit (Qiagen, Hilden, Germany) or DNeasy Blood \& tissue kit (Qiagen, Hilden, Germany). cDNA was produced according to standard protocols. Primers for cDNA genotyping were as follows: forward primer cF (5'-GAGAGTTGCCGGACTTTCAG$\left.3^{\prime}\right)$, and two reverse primers; cRa (5'-TCACAGAGGAACTGGGCAAT-3') and cRb (5'-ATTCAGGCTGCGCAACTGTTGGG-3') in GeneTrap vector (Figure 1). Length of the amplified wild-type (WT) allele was $205 \mathrm{bp}$, and mutant allele $278 \mathrm{bp}$. Primers for genomic genotyping were; one forward primer gF (5'-TGTCTGACTCACTCTTTTCTTTATTCC-3'), and two reverse primers; gRa (5'-AGGAGAGCCAGACAAAACCA-3'), and gRb (5'-CTGGTGAGGCCAAGTTTGTT-3'). WT allele was 177 bp and mutant allele 193 bp. PCR conditions are available on request.

\section{Tissue Preparations}

Heterozygous and WT mice were followed up in a cohort study, in which necropsies were performed at 3-month intervals, beginning at 3 months up to 21 months. Mice used in the study had $89 \%$ to $100 \%$ C57BL/6Rcc genetic 
background. Analysis in each age group included heterozygous mice and age-matched WT controls from the same litters (2-3 litters per age group). In each age group and in both genotype classes both genders were represented close to 1:1. After $\mathrm{CO}_{2}$ anesthesia and neck dislocation, tissues were collected. Pituitary gland, thyroid/ parathyroid, adrenal glands, pancreas, brain, kidneys, and liver were collected; other tissues were also collected if macroscopic abnormalities were detected. Total weights of the mice and the relative weights of their liver, spleen, and kidneys (organ weight/total weight of mouse $\times 100$ ) were measured. Small tissues were fixed up to 2 hours and larger ones overnight in cold $4 \%$ paraformaldehyde. The pituitary gland was retained on top of the skull and fixed for 1.5 hours followed by decalcification of 2 hours. Fixed tissues were embedded in paraffin and sectioned at $5 \mu \mathrm{m}$. Hematoxylin and eosin $(\mathrm{H} \& \mathrm{E})$ staining of the pituitary gland was performed in approximately every $50 \mu \mathrm{m}$ to thoroughly analyze the histopathological features of the organ. From other tissues all macroscopic abnormalities were further examined at microscopic level.

\section{Immunohistochemical Analyses}

Hormonal status of the tumors was assessed by GH (1/400 dilution, A0570, DakoCytomation, Glostrup, Denmark), PRL (1/4000, A0569, DakoCytomation, Glostrup, Denmark), and ACTH (1/2000, PA1-36035, AH diagnostics, Århus, Denmark) immunohistochemistry. In addition, expression of AIP (1/100, ab48833, Abcam, Cambridge, UK), ARNT (1/50, ab14829, Abcam, Cambridge, UK), ARNT2 (1/100, sc5581/ clone M-165, Santa Cruz, Santa Cruz, CA), HIF-1 $\alpha$ (1/200, NB100-479, Novus Biologicals, Littleton, CO), estrogen-receptor $\alpha(E R \alpha)$ (1/100, ab80922, Abcam, Cambridge, UK), and Ki-67 proliferation marker (1/250, ab15580, Abcam, Cambridge, UK) was investigated. Heat-induced antigen retrieval was performed in a microwave oven (20-25 minutes) primarily in $(\mathrm{pH} 6)$ citrate or alternatively in $(\mathrm{pH} 9) \mathrm{TE}$ buffer (AIP and ARNT2). Antibodies in the above mentioned dilutions were incubated on slides for 1 hour in room temperature or alternatively overnight in $+4^{\circ} \mathrm{C}(\mathrm{GH}, \mathrm{PRL}$, and ACTH). Power Vision rabbit or rabbit/mouse Poly-HRP immunohistochemistry $(\mathrm{IHC})$ Kit with $\mathrm{DAB}$ as a chromogen (ImmunoVision Technologies, Norwell, MA) was used for antibody detection. Finally, sections were counterstained with hematoxylin.

The AIP protein and the hormone IHCs were scored either negative or positive. The staining intensity of ARNT, ARNT2, and HIF- $1 \alpha$ was scaled as negative (0), weak (1), intermediate (2), or high (3). In the case of macroadenomas the Ki-67 proliferation index ( $\mathrm{PI}=$ the number of $\mathrm{Ki}-67-$ positive cells among the total number of resting cells) was evaluated from 100 to 500 tumor cells in the area of strongest expression. If the pituitary tumor contained less than 100 cells, all of the cells were counted. Only distinctly stained nuclei were considered as immunopositive. ER $\alpha$ intensity was scaled as negative (0), weak (1), intermediate (2), or high (3). The percentage of ER $\alpha$-positive cells was evaluated on a scale of 0 to $4(0 \%=0,1$ to $25 \%=1$,
$26-50 \%=2,51-75 \%=3$, and $>75 \%=4)$. Finally, the $\mathrm{Q}$-score method (intensity score $+\%$ cells stained, range $0-7$ ) was used to quantify the ER $\alpha$ expression. ${ }^{20}$

\section{LOH Analysis}

To assess loss of heterozygosity ( $\mathrm{LOH}$ ), fresh pituitary tumor DNA from two $\mathrm{Aip}^{+/-}$mice was sequenced. Multiplex PCR was performed with a forward primer targeted in the wild-type sequence (TGTGTGCTTTTGTACCTGTTGT), a forward primer in the insertion (ATGGCAGCACTGCATAATTC), and a reverse primer in the wild-type sequence (AGCATTTTGAGAAAAGAAAAATTAACA). The amplified WT allele was $166 \mathrm{bp}$ and the mutant was 162 bp. Allelic imbalance was scored by comparing the ratios of the allele peak heights in sequencing graphs of 30bp-long sequence stretches between normal and tumor samples as described previously. ${ }^{21,22}$ The cutoffs for $\mathrm{LOH}$ were $<0.60$ and $>1.67$.

\section{Q-PCR}

RNA was extracted from livers of 18-month-old $\mathrm{Aip}^{+/-}$ and $\mathrm{Aip}^{+/+}$mice with RNeasy Mini Kit (Qiagen, Hilden), and CDNA was produced by standard methods. The relative expression of Igf-1 (insulin-like growth factor 1) was determined using TaqMan chemistry and 7500 Fast Real-Time PCR system (Applied Biosystems, Foster City, CA). The lgf-1 probe was Mm00439560 (Applied Biosystems) and the relative mRNA copy numbers were normalized against $\beta$-actin housekeeping gene (4352341E; Applied Biosystems).

\section{Statistical Analyses}

The $\chi^{2-}$ statistic was used to investigate the deviation of live Aip embryos from the expected Mendelian 1:2:1 ratio. Comparisons between the groups were drawn through the Student's t-test, and in cases of asymmetric variables the Wilcoxon-Mann-Whitney U-test. The Fisher's exact test or Fisher Freeman-Halton extension test was used to test statistical significances. Correlations were assessed by Spearman rank correlation.

\section{Results}

\section{Generation of Aip ${ }^{+/-}$Mice and Genotyping}

The Aip mutation was generated by inserting a gene trap vector construct into an intronic region of genomic DNA between Aip exons 2 and 3 (ENSMUSTO0000117831) (BayGenomics, University of California, Davis, CA). ${ }^{19}$ The inserted vector construct creates an artificial splicing site after 34 codons (34/331) (Figure 1A). No leakage of the construct was observed when tested by Q-PCR and Western blotting. ${ }^{10}$ Mice were genotyped by multiplex PCR either from cDNA or genomic DNA (Figure 1B).

The crossings of heterozygous mice yielded one live $\mathrm{Aip}^{-1-}, 37 \mathrm{Aip}^{+/-}$, and $22 \mathrm{Aip}^{+/+}$embryos when analyzed 
A

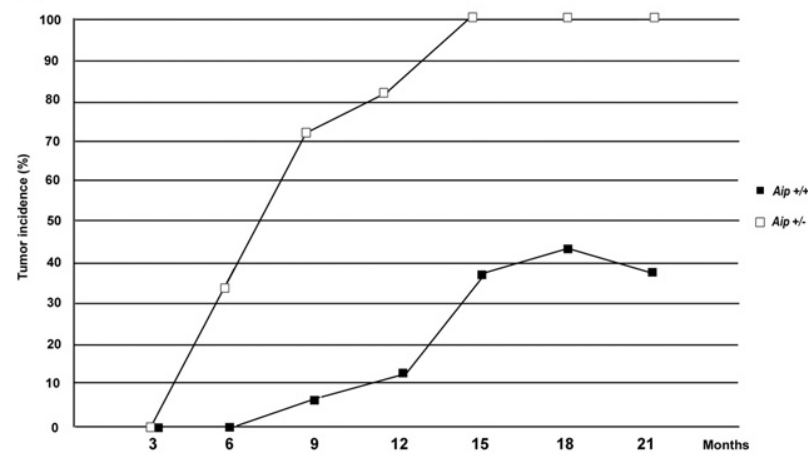

B

\begin{tabular}{|c|c|c|}
\hline & Age (months) & Mice with GH-secreting adenomas \\
\hline $\begin{array}{l}\text { Aip }+1 / \\
\text { Aip }+/+\end{array}$ & 3 & : \\
\hline $\begin{array}{l}\text { Aip }+1 / \\
\text { Aip t/+ }\end{array}$ & 6 & $83.3 \%$ \\
\hline $\begin{array}{l}\text { Aip }+/ \\
\text { Aip } t / \%\end{array}$ & 9 & $84.6 \%$ \\
\hline $\begin{array}{l}\text { Aip }+/ \\
\text { Aip }+/ /\end{array}$ & 12 & $88.9 \%$ \\
\hline $\begin{array}{l}\text { Aip }+1 / \\
\text { Aip }+/+\end{array}$ & 15 & $\begin{array}{l}94.7 \% \\
33.3 \%\end{array}$ \\
\hline $\begin{array}{l}\text { Aip }+1 / \\
\text { Aip }+/+\end{array}$ & 18 & $100 \%$ \\
\hline $\begin{array}{l}\text { Aip }+/ \\
\text { Aip }+/ /\end{array}$ & 21 & $\begin{array}{l}66.7 \% \\
33.3 \%\end{array}$ \\
\hline
\end{tabular}

Figure 2. Incidence of pituitary tumors in Aip $^{+/-}$and Aip ${ }^{+/+}$mice. A: Incidence curves of pituitary adenomas detected in 3-month interval groups of $\mathrm{Aip}^{+/-}$and $\mathrm{Aip^{+/+ }}$ mice. B: Proportions of GH-secreting adenomas in the analyzed groups.

at the E12.5 stage. This deviates significantly from the expected Mendelian 1:2:1 ratio $\left(\chi^{2}=17.97, P<0.001\right)$. No living knock-out $\left(\right.$ Aip $\left.^{-1-}\right)$ pups were born. The result is consistent with the study of Lin et al where half of the Aip knockout embryos died before E10.5 and the remaining knockout fetuses survived no later than E14.5. ${ }^{17}$

\section{Aip $^{+/-}$Promotes GH Secreting Pituitary Adenoma Development in Vivo}

Altogether 88 heterozygous Aip $^{+/-}$and 58 WT Aip ${ }^{+/+}$mice were examined. Among the $88 \mathrm{Aip}^{+/-}$mice, 69 mice (78.4\%) developed one or more pituitary tumors, whereas only $12(20.7 \%)$ of the 58 WT littermates displayed this tumor type (Figure 2A). Thus, pituitary tumors were significantly more frequent among $\operatorname{Aip}^{+/-}$mice $\left(P<10^{-6}\right)$. $\mathrm{Aip}^{+1-}$ mice showed first pituitary lesions, localized in the pars distalis corresponding to the human anterior pituitary, at six months of age. Several macroscopically visible macroadenomas were detected among heterozygous mice at the older age groups (Figure 3, A and B). The pituitary tumor phenotype reached full penetrance at the age of 15 months (Figure 2A). The purity of genetic background did not have an effect on the incidence of pituitary adenomas, as Aip ${ }^{+/-}$ mice with variable C57BL/6Rcc genetic background (89\% to $100 \%$ ) all developed pituitary adenomas by 15 months of age (data not shown). No differences in pituitary adenoma formation between sexes were de-
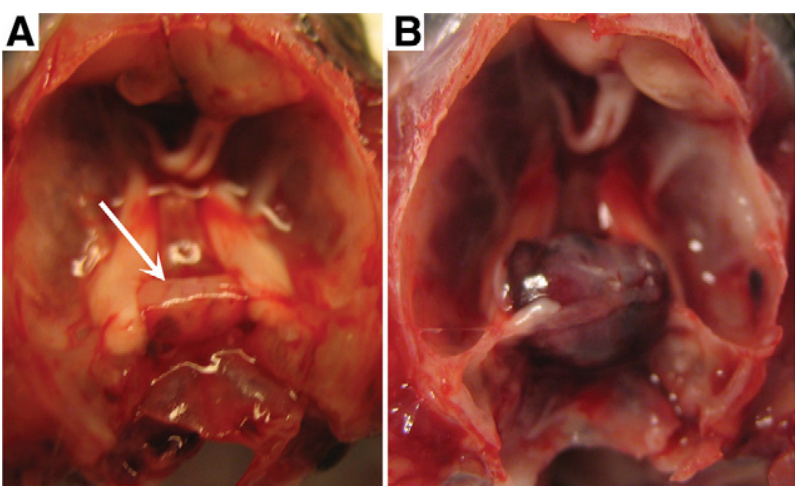

Figure 3. Normal pituitary gland and pituitary with macroadenoma. A: The normal pituitary gland of a wild-type mouse. B: Macroadenoma of a heterozygous $A i^{+/-}$mouse. The pituitary gland is depicted by a white arrow

tected ( $P=0.21$, Fisher's exact test, see Supplemental Table S1 at $h$ ttp://ajp.amjpathol.org).

Aip $^{+/-}$mice were prone to develop multiple primary pituitary tumors already at the age of six months, whereas multifocal pituitary tumors were detected among the WT mice at much older age groups (15-21 months) (see Supplemental Table S1 at http://ajp.amjpathol.org). The multifocal origin of adenomas was confirmed by sectioning through pituitary glands.

The hormonal status of the tumors was defined by IHC analyses. The majority of the Aip ${ }^{+/-}$mice developed $\mathrm{GH}$ secreting adenomas (61/69, 88\%) (Figure 2B). Also, prolactinomas were relatively common among heterozygous mice (Figure 4, A-C). In addition, two mixed GH/PRL and one ACTH secreting tumor were seen (see Supplemental Table S1 at http://ajp.amjpathol.org). The predominance of $\mathrm{GH}$-secreting adenomas is consistent with the finding that AIP mutations predispose primarily to somatotropi-
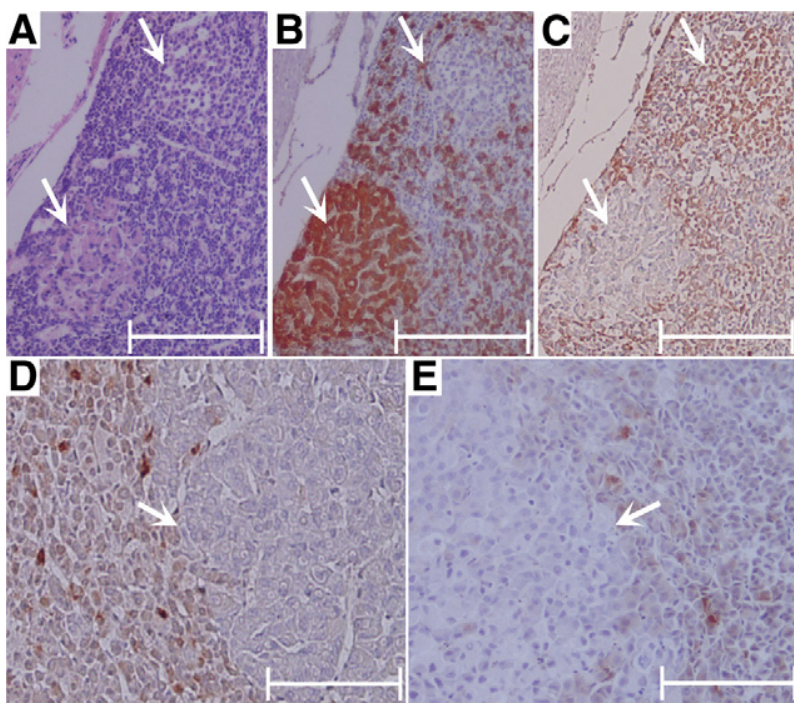

Figure 4. Immunostaining of GH, PRL, and AIP. A: H\&E staining of a pituitary gland with two pituitary adenomas. B: GH immunostaining; one GH-positive and one GH-negative pituitary tumor observed in the pars distalis of a heterozygous $\mathrm{Aip}^{+/-}$mouse. C: PRL immunohistochemistry of the corresponding lesions. Scale bars $=200 \mu \mathrm{m}$. Negative AIP staining of GH-positive (D) and PRL-positive (E) adenomas from an $\mathrm{Aip}^{+/-}$mouse. Scale bars $=100 \mu \mathrm{m}$ Tumors are depicted by white arrows. HE, GH, and PRL staining was performed using serial sections from the same $A \mathrm{ip}^{+/-}$mouse. 
nomas in humans. The majority of the adenomas in Aip $^{+/+}$mice were prolactinomas $(25 / 27,92.6 \%)$, but also two GH/PRL tumors were detected (7.4\%). WT mice did not develop purely $\mathrm{GH}$ secreting adenomas.

\section{Loss of Aip in Pituitary Tumors}

Fresh tumor tissue from two $\mathrm{Aip}^{+/-}$mice was available for $\mathrm{LOH}$ studies. The cutoffs for $\mathrm{LOH}$ were $<0.60$ and $>1.67$ for mutant and WT allele, respectively. ${ }^{21}$ The allele peak ratios in the normal/tumor pairs were 2.19 and 2.08, indicating reduction of the WT allele in these two tumor samples. Complete loss of the WT allele was never seen due to normal tissue contamination.

The expression of the AIP protein in pituitary tumors was studied with IHC. All of the 38 stained $\mathrm{GH}$-positive adenomas from $\mathrm{Aip}^{+/-}$mice revealed negative AIP immunostaining (Figure 4D). Also the majority of the PRLpositive adenomas (22/26, 84.6\%) (Figure 4E) as well as one ACTH immunopositive tumor showed lack of AIP protein. The finding of four prolactinomas with positive AIP staining suggests that some or all of these lesions may have arisen incidentally and were not related to the germline defect. All of the pituitary adenomas in the WT mice showed positive AIP protein expression.

\section{Other Phenotypic Effects of Aip ${ }^{+/-}$}

Viability or total weight did not differ between WT and heterozygous mice (data not shown). The relative weights (organ weight/total weight $\times 100$ ) of liver, kidney, and spleen were the same between Aip $^{+/-}$mice and their Aip $^{+/+}$littermates up to 12 months. Aip ${ }^{+/-}$mice $\geq 15$ months showed a trend toward increased relative organ weights compared to the WT mice, but these differences were not significant (Figure 5, A and B). Twenty-one months observation did not reveal excess of any other tumor type in $\mathrm{Aip}^{+/-}$mice. Aip IHC for one lung, five liver, and two kidney tumors from Aip $^{+/-}$mice was performed. All tumors showed AIP protein expression, suggesting an incidental association. A slight excess of macroscopically visible hyperplasia of adrenal glands was detected in $\mathrm{Aip}^{+/-}$mice $\left(\mathrm{Aip}^{+/-} ; 7 / 87\right.$ versus $\mathrm{Aip}^{+/+} ; 2 / 58, P=$ 0.16). Histopathological examination, however, did not reveal any neoplastic growth.

\section{Mice with Aip-Deficient Somatotropinomas Have Elevated Igf-1 Levels}

To assess the functionality of $\mathrm{GH}$ secreted by Aip-deficient somatotropinomas, expression of lgf-1 in liver was measured by quantitative PCR. Seven 18-month-old $\mathrm{Aip}^{+/-}$ mice and 11 WT mice were studied. Among the WT mice there were three animals having GH/PRL secreting adenoma. The mean lgf-1 expression for seven Aip $^{+/-}$mice with $\mathrm{GH}$ adenomas was $1.9 \pm 0.26$ (SD), and for the eight WT mice not having GH secreting adenomas $1.4 \pm 0.22$ (SD). The relative lgf- 1 expression value for the WT mice with GH secreting adenoma was $1.8 \pm 0.11$ (SD), thus being in line with the expressions measured from the het-

\section{A}

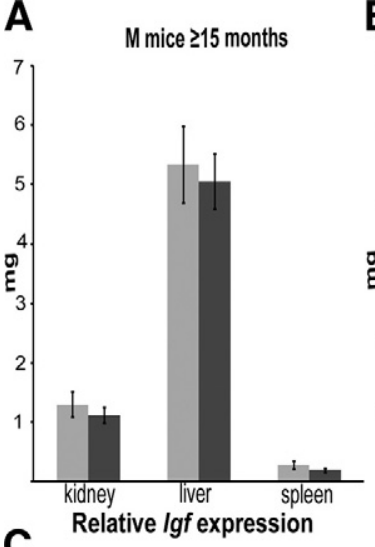

B

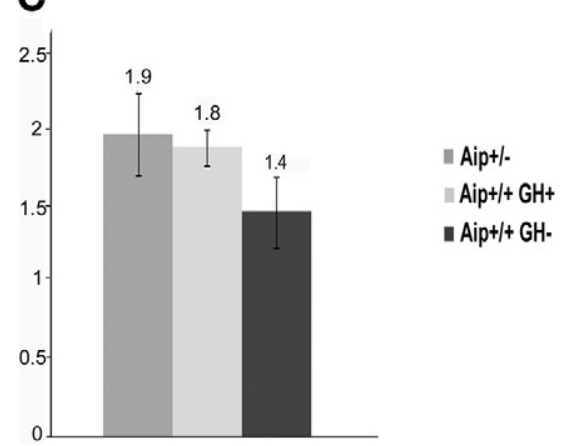

Figure 5. Relative organ weights and $I g f-1$ expression levels of $A i P^{+/-}$and Aip $^{+/+}$mice. Weights of kidney, liver, and spleen in (A) male (M) and (B) female (F) mice. Calculations were made by dividing organ weight by total weight and multiplying by 100 . Error bars indicate standard deviations. C: Relative Igf- 1 expression levels from livers of 18 -month-old mice. Aip ${ }^{+/-}$, heterozygous mice with GH-secreting adenomas; $\mathrm{Aip}^{+/+} \mathrm{GH+}$, WT mice with GH-secreting adenomas; Aip ${ }^{+/+}$GH-, WT mice without GH-secreting adenomas.

erozygous mice (Figure 5C). Altogether the $\mathrm{Aip}^{+/-}$mice with somatotropinomas had significantly elevated Igf-1 expression levels compared to the WT mice not having GH secreting adenomas ( $P=0.002$, Student's $t$-test).

\section{Aip-Deficient Pituitary Tumors Show High Proliferation Rate}

To evaluate the proliferation rate in Aip mutation positive and negative tumors, Ki-67 IHC analysis was performed. The $\mathrm{Ki}-67$ protein is expressed in all phases of the active cell cycle (G1, S, and M phase) but is absent in resting (G0) cells. The Aip mutation positive tumors had a significantly higher proliferation rate compared to wild-type adenomas $(P=0.014)$ (Table 1; also see Supplemental Table S2 at

Table 1. Ki-67 Proliferation Indices (PI) Observed in Aip-Deficient and -Proficient Pituitary Tumors

\begin{tabular}{cccc}
\hline Genotype & Tumors (n) & Average PI (SD) & \\
\hline Aip $^{+/-}$ & & & $P .1( \pm 4.7)$ \\
GH & 16 & $10.1( \pm 3.6)$ & \\
PRL & 7 & $3.6 \%( \pm 3.1)$ & \\
Aip $^{+/+}$ & 13 & & \\
PRL & 13 & & \\
\hline
\end{tabular}

*Two-sided $P$ value with Student's $t$-test; difference between mutation-positive and mutation-negative tumors. 


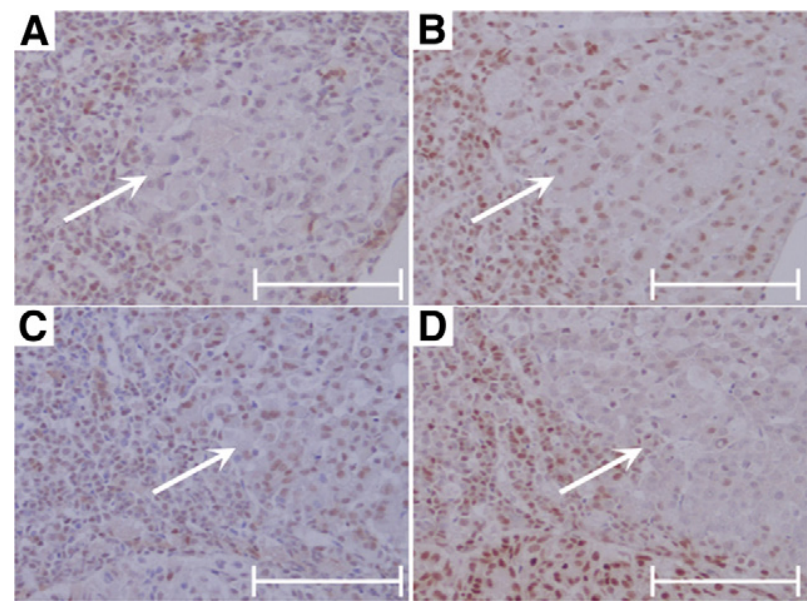

Figure 6. ARNT and ARNT2 immunohistochemical staining in Aip-deficient tumors. A and B: A GH-positive adenoma showing negative ARNT (A) and positive ARNT2 (B) staining. C and D: A PRL-secreting pituitary tumor showing positive ARNT $(\mathbf{C})$ and negative ARNT2 $(\mathbf{D})$ immunoreaction. Scale bars $=50$ $\mu \mathrm{m}$. Tumors are depicted by white arrows.

http://ajp.amjpathol.org). No correlation between age and proliferation rate was detected (Spearman rank correlation; rho $=-0.12, P=0.59)$. The hormonal status of Aip-deficient tumors did not unambiguously correlate with the PI values ( $P=0.05$, Student's $t$-test), although prolactinomas showed higher average PI when compared to $\mathrm{GH}$ tumors, $10.1 \pm 3.6(\mathrm{SD})$ versus $6.1 \pm 4.7$ (SD), respectively.

\section{Estrogen-Receptor $\alpha$ Expressions in Aip-Deficient and-Proficient Tumors}

$\mathrm{IHC}$ was used to examine the expression of $\mathrm{ER} \alpha$ in Aiprelated tumorigenesis. The study comprised 30 Aip-deficient adenomas (14 PRL and $16 \mathrm{GH}$ tumors) and eight Aip-proficient prolactinomas. All Aip-proficient tumors and 29/30 of Aip-deficient tumors were positive for ER $\alpha$. ER $\alpha$ showed a distinct nuclear expression (see Supplemental Figure S1 at http://ajp.amjpathol.org). The Aip-proficient tumors showed significantly higher $\mathrm{ER} \alpha$ expressions compared to the Aip-deficient adenomas ( $\mathrm{GH}$ and $\mathrm{PRL})$, mean $4.6 \pm 0.70(\mathrm{SD})$ versus $3.8 \pm 1.37(\mathrm{SD})$, respectively $(P=$ 0.02 , Student's $t$-test). However, no statistically significant difference between Aip-deficient and -proficient tumors was found when only prolactinomas were compared $(P=0.11)$. $\mathrm{ER} \alpha$ expressions did not correlate with proliferation rates or gender (rho $=-0.31, P=0.65$, Spearman rank correlation; $P=0.34$, Student's $t$-test, respectively). No statistical significance between ARNT or ARNT2 deficiency and ER $\alpha$ expression was detected ( $P=0.37$, Student's $t$-test). ER $\alpha$ was present in all normal pituitaries, and the expressions were similar between Aip $^{+/-}$and Aip ${ }^{+/+}$mice, $5.7 \pm 0.8$ $(\mathrm{SD})$ and $5.6 \pm 0.7(\mathrm{SD})$.

\section{ARNT Protein Imbalance in Aip-Deficient Pituitary Tumors}

ARNT and ARNT2 IHCs showed a total lack of ARNT in 14 and the total lack of ARNT2 protein in 40 Aip-deficient
Table 2. ARNT and ARNT2 Protein Imbalance in Aip-Deficient and -Proficient Pituitary Tumors

\begin{tabular}{|c|c|c|c|}
\hline Genotype & $\begin{array}{l}\text { Tumors Lacking } \\
\text { ARNT, n (\%) }\end{array}$ & $\begin{array}{l}\text { Tumors Lacking } \\
\text { ARNT2, n (\%) }\end{array}$ & \\
\hline \multicolumn{4}{|l|}{$\mathrm{Aip}^{+/-}$} \\
\hline $\mathrm{GH}$ & $11 / 47(23.4 \%)$ & $36 / 47(76.6 \%)$ & $P<0.007^{*}$ \\
\hline $\begin{array}{r}\text { PRL } \\
A_{i j}^{+/+}\end{array}$ & $3 / 7(43.9 \%)$ & $4 / 7(57.1 \%)$ & \\
\hline PRL & $0 / 14$ & $0 / 14$ & \\
\hline
\end{tabular}

${ }^{*}$ The $\chi^{2}$ statistic was used to investigate the loss of either ARNT or ARNT2 in Aip-deficient GH tumors.

tumors (Figure 6, A-D, Table 2). GH-secreting Aip-deficient tumors showed more often lack of ARNT2 than ARNT $\left(\chi^{2}=7.28, P<0.007\right)$. Remarkably, almost all Aip-deficient tumors expressed only either ARNT or ARNT2 (49/53, 92.5\%, $P<10^{-5}$, Fischer's exact test). In contrast, both proteins were present in all Aip-proficient tumors (10/10 in WT animals and 4/4 in heterozygous animals, $100 \%)$. No differences in proliferation rates between ARNT $(n=4)$ and ARNT2-deficient $(n=9)$ tumors were detected; median $4 \%$ (range, 2 to $8 \%$ ) versus $4 \%$ (2 to $10 \%)$, respectively ( $P=0.73$, Mann-Whitney $U$-test).

To examine the hypoxia response in Aip-deficient and -proficient tumors, $\mathrm{HIF}-1 \alpha \mathrm{IHC}$ was performed. A total of 50 Aip-deficient and 13 Aip-proficient tumors were studied. $\mathrm{HIF-1} \alpha$ was present in 46/50 of Aip-deficient tumors and in all proficient samples, suggesting the activation of this oncogenic pathway (see Supplemental Figure S1 at $h t t p: / /$ ajp.amjpathol.org). Staining intensity averages were $1.8 \pm$ 0.9 (SD) and $2.0 \pm 0.4$ (SD) in Aip-deficient and -proficient tumors, respectively ( $P=0.26$, Student's $t$-test). PRL secreting adenomas showed significantly higher HIF- $1 \alpha$ expression when compared to $\mathrm{GH}$-positive adenomas $(P=$ 0.002). Expression of HIF-1 $\alpha$ was found to be even between ARNT and ARNT2 negative tumors. ( $P=0.92$, Fischer's exact Probability with Freeman-Halton extension). Similarly, there was no correlation between $\mathrm{HIF}-1 \alpha$ intensities and proliferation rates ( $P=0.51$, Mann-Whitney $U$-test). For reference, adjacent normal pituitary tissue had a weak cytoplasmic expression or did not display $\mathrm{HIF}-1 \alpha$ staining.

\section{Discussion}

In the present study, an Aip ${ }^{+/-}$mouse model was generated to depict pituitary tumorigenesis caused by human germline AIP mutations. Heterozygous Aip mutation increased dramatically the incidence of pituitary adenomas in C57BL/6Rcc mice. First tumors were detected at six months of age. No tumors were detected at the age of three months. It is, however, possible that pituitary adenomas in this age group are relatively rare and the lesions might be too small to detect with routine HE-staining. No excess of any other tumor type was detected. $\mathrm{GH}$-secreting adenomas dominate in Aip ${ }^{+/-}$mice even though prolactinomas, two mixed $\mathrm{GH} / \mathrm{PRL}$, and an ACTH secreting adenoma were also detected. As compared with human AIP mutation carriers, mixed $\mathrm{GH} / \mathrm{PRL}$ adenomas were proportionally less frequent in our mouse model. It has been estimated that mammosomatotrophs (cells releasing both $\mathrm{PRL}$ and $\mathrm{GH}$ ) are rela- 
tively common in human pituitary (25 to $50 \%$ ). In mice the percentage of these cells has been reported to be considerably smaller (0.6\% to less than $20 \%$ ), which may explain the relatively low frequency of mixed adenomas in $\mathrm{Aip}^{+/-}$ mice. ${ }^{23}$ Overall, the Aip ${ }^{+/-}$mouse model greatly resembles the human phenotype reproducing a close to identical tumor phenotype, suggesting that the factors underlying Aipdeficient tumorigenesis are similar in mice and humans. ${ }^{2,3,5,9}$ The only major difference observed between the human and mouse phenotype was the complete penetrance of pituitary tumors in mice; all heterozygous mice developed pituitary tumor(s) when aged up till 15 months (Figure 2). To our knowledge, Aip ${ }^{+/-}$mouse is by far the most pituitary adenoma prone model currently available, emphasizing the fundamental importance of AIP for tumorigenesis in this organ. ${ }^{24-26}$

Acromegaly, resulting from GH secretion, is also known to cause an overgrowth of all organ systems, bones, joints, and soft tissues. ${ }^{1} \mathrm{GH}$ is known to regulate the abundance of lgf-1 expression in the liver. ${ }^{27}$ The present study showed that liver lgf- 1 expression of somatotropinoma bearing Aip ${ }^{+/-}$mice was increased as compared with control animals, supporting the view that the GH secreted by Aip-deficient somatotropinomas is functional (Figure 5C). Along the same lines, we detected signs of increased relative organ weights in $\mathrm{Aip}^{+/-}$mice $\geq 15$ months (Figure 5, A and B). However, the weight differences were not statistically significant, perhaps due to the relatively small number of mice in each group.

Lin and coworkers reported that $56 \%$ of heterozygous Aip mice displayed a reduced liver size and weight due to a patent ductus venosus. ${ }^{18}$ In our study, Aip ${ }^{+/-}$mice had the same or even slightly increased relative liver weight compared with WT littermates (Figure 5). The reason for the discrepancy between these studies can be differences in the placement of the germ line mutation to produce the Aip inactivation or possibly the different C57BL substrains used for inbreeding. ${ }^{28}$

Ki-67 analysis showed that Aip-associated tumors had higher proliferation rates as compared with the WT pituitary adenomas $(P=0.014$, Table 1 , see Supplemental Table S2 at $h$ ttp://ajp.amjpathol.org). Because of lack of tumor material we were not able to perform $\mathrm{Ki}-67 \mathrm{IHC}$ in human AIP mutation positive tumors. However, the proliferation average detected in tumors of WT mice $(3.6 \%)$ is well comparable to values detected in sporadic human pituitary tumors (1 to $4 \%$ ). ${ }^{29-31}$ In humans the AIP mutation positive tumors have been reported to be larger and to have a poorer response to somatostatin analogues. ${ }^{5,9}$ Our result supports the view that AIP mutation positive adenomas have a more aggressive disease profile. AIPassociated tumors may require more frequent follow-up and development of tailored therapeutic strategies. The estrogen receptor signaling pathway is known to act in biosynthesis and secretion of hormones of the anterior pituitary and to stimulate the proliferation of lactotropes and gonadotropes. ${ }^{32}$ Protein expression of ER $\alpha$ was uniform between Aip-deficient and -proficient prolactinomas. In contrast, the Aip-deficient GH-positive tumors had lower ER $\alpha$ expression when compared to prolactinomas. This is in accordance with earlier studies reporting that prolactinomas have a tendency to show higher $\mathrm{ER} \alpha$ levels as compared with $\mathrm{GH}$-secreting adenomas. ${ }^{33,34} \mathrm{Al}$ though we were not able to compare $\mathrm{ER} \alpha$ expression between Aip-deficient and -proficient GH-secreting tumors due to the rarity of WT GH-secreting tumors, these results suggest that $E R \alpha$ may not be a key factor in Aip-associated pituitary tumorigenesis.

Presence of HIF- $1 \alpha$ indicated the activation of the hypoxia response both in Aip-deficient and -proficient pituitary adenomas. The level of HIF- $1 \alpha$ was significantly higher in Aip-proficient prolactinomas $(P=0.01)$. It has been, accordingly, reported in humans that prolactinomas have a tendency to show higher HIF-1 $\alpha$ protein expression levels as compared with $\mathrm{GH}$ secreting adenomas. ${ }^{35}$

ARNT is a known heterodimerization partner of $H I F-1 \alpha$ to form an active HIF-1 complex, but ARNT2 has been shown to be able to compensate the lack of ARNT through binding with HIF- $1 \alpha .{ }^{36-38}$ Our ARNT and ARNT2 IHCs revealed the total lack of either ARNT or ARNT2 in Aip-deficient mouse pituitary tumors (Table 2). This finding is in agreement with our earlier work where ARNT protein was significantly reduced in human AIP mutation positive pituitary tumors (ARNT2 was not studied in that work). ${ }^{10}$ Strikingly, we found that almost always there was loss of either ARNT or ARNT2, but not both, in the Aipdeficient mouse lesions $\left(P<10^{-5}\right)$. While the mechanisms behind this form of haploinsufficiency remain to be elucidated, this result suggests that the signaling through ARNT and ARNT2 is a key factor in the genesis of pituitary tumors after AIP function is lost.

In conclusion, $\mathrm{Aip}^{+/-}$mice display a disease phenotype which is strikingly similar to that reported in humans. AIP/Aip germline mutations appear to associate only with pituitary adenomas. In both human and mouse, GH-secreting adenoma is the most common tumor type accounting for $80 \%$ and $88 \%$ of AIP/Aip associated pituitary tumors, respectively. The dramatically increased somatotropinoma risk associated with heterozygous AIP germline mutations in mice and humans makes AIP an attractive candidate gate keeper gene in somatotrophs. In addition, our data support the previously presented notion of a more aggressive disease profile in AIP-deficient pituitary tumors.

The generation of this disease model provides an important tool to further dissect and elucidate the molecular basis of pituitary tumorigenesis. It is also potentially valuable in efforts to develop therapeutic strategies for management of patients with treatment resistant pituitary adenomas.

\section{Acknowledgments}

We are grateful to Laboratory Animal Centre at Biomedicum and Ruskeasuo for careful animal care; lina Vuoristo, IngaLill Svedberg, and Mairi Kuris for excellent technical assistance; Elina Maaranen and Essi Kaiharju for guidance in mouse preparation; and Anne Reijula for tissue processing.

\section{References}

1. Heaney AP, Melmed S: Molecular targets in pituitary tumours. Nat Rev Cancer 2004, 4:285-295 
2. Vierimaa $\mathrm{O}$, Georgitsi M, Lehtonen R, Vahteristo P, Kokko A, Raitila A, Tuppurainen K, Ebeling TM, Salmela PI, Paschke R, Gundogdu S, De Menis E, Makinen MJ, Launonen V, Karhu A, Aaltonen LA: Pituitary adenoma predisposition caused by germline mutations in the AIP gene. Science 2006, 312:1228-1230

3. Georgitsi M, Raitila A, Karhu A, Tuppurainen K, Makinen MJ, Vierimaa O Paschke R, Saeger W, van der Luijt RB, Sane T, Robledo M, De Menis E, Weil RJ, Wasik A, Zielinski G, Lucewicz O, Lubinski J, Launonen V, Vahteristo P, Aaltonen LA: Molecular diagnosis of pituitary adenoma predisposition caused by aryl hydrocarbon receptor-interacting protein gene mutations. Proc Natl Acad Sci USA 2007, 104:4101-4105

4. Tichomirowa MA, Daly AF, Beckers A: Familial pituitary adenomas. J Intern Med 2009, 266:5-18

5. Leontiou CA, Gueorguiev M, van der Spuy J, Quinton R, Lolli F, Hassan S, Chahal HS, Igreja SC, Jordan S, Rowe J, Stolbrink M, Christian HC, Wray J, Bishop-Bailey D, Berney DM, Wass JA, Popovic V, Ribeiro-Oliveira A, Jr, Gadelha MR, Monson JP, Akker SA, Davis JR, Clayton RN, Yoshimoto K, Iwata T, Matsuno A, Eguchi K, Musat M, Flanagan D, Peters G, Bolger GB, Chapple JP, Frohman LA, Grossman $\mathrm{AB}$, Korbonits $\mathrm{M}$ : The role of the Aip gene in familial and sporadic pituitary adenomas. J Clin Endocrinol Metab 2008, 93:2390-2401

6. Georgitsi M, Karhu A, Winqvist R, Visakorpi T, Waltering K, Vahteristo $\mathrm{P}$, Launonen $\mathrm{V}$, Aaltonen LA: Mutation analysis of aryl hydrocarbon receptor interacting protein (AIP) gene in colorectal, breast, and prostate cancers. Br J Cancer 2007, 96:352-356

7. Raitila A, Georgitsi M, Karhu A, Tuppurainen K, Makinen MJ, Birkenkamp-Demtroder K, Salmenkivi K, Orntoft TF, Arola J, Launonen V, Vahteristo $P$, Aaltonen LA: No evidence of somatic aryl hydrocarbon receptor interacting protein mutations in sporadic endocrine neoplasia. Endocr Relat Cancer 2007, 14:901-906

8. Raitila A, Georgitsi M, Bonora E, Vargiolu M, Tuppurainen K, Makinen MJ, Vierimaa O, Salmela PI, Launonen V, Vahteristo P, Aaltonen LA Romeo G, Karhu A: Aryl hydrocarbon receptor interacting protein mutations seem not to associate with familial non-medullary thyroid cancer. J Endocrinol Invest 2009, 32:426-429

9. Daly AF, Vanbellinghen JF, Khoo SK, Jaffrain-Rea ML, Naves LA Guitelman MA, Murat A, Emy P, Gimenez-Roqueplo AP, Tamburrano G, Raverot G, Barlier A, De Herder W, Penfornis A, Ciccarelli E, Estour B, Lecomte P, Gatta B, Chabre O, Sabate MI, Bertagna X, Garcia Basavilbaso N, Stalldecker G, Colao A, Ferolla P. Wemeau JL, Caron P, Sadoul JL, Oneto A, Archambeaud F, Calender A, Sinilnikova O, Montanana CF, Cavagnini F, Hana V, Solano A, Delettieres D, LuccioCamelo DC, Basso A, Rohmer V, Brue T, Bours V, Teh BT, Beckers A: Aryl hydrocarbon receptor-interacting protein gene mutations in familial isolated pituitary adenomas: analysis in 73 families. J Clin Endocrinol Metab 2007, 92:1891-1896

10. Heliövaara E, Raitila A, Launonen V, Paetau A, Arola J, Lehtonen H, Sane T, Weil RJ, Vierimaa O, Salmela P, Tuppurainen K, Makinen M, Aaltonen LA, Karhu A: The expression of AIP-related molecules in elucidation of cellular pathways in pituitary adenomas. Am J Pathol 2009, 175:2501-2507

11. Petrulis JR, Perdew GH: The role of chaperone proteins in the aryl hydrocarbon receptor core complex. Chem Biol Interact 2002, 141:25-40

12. Rankin EB, Giaccia AJ: The role of hypoxia-inducible factors in tumorigenesis. Cell Death Differ 2008, 15:678-685

13. Matthews J, Gustafsson JA: Estrogen receptor and aryl hydrocarbon receptor signaling pathways. Nucl Recept Signal 2006, 4:e016

14. Brunnberg S, Pettersson K, Rydin E, Matthews J, Hanberg A, Pongratz I: The basic helix-loop-helix-PAS protein ARNT functions as a potent coactivator of estrogen receptor-dependent transcription. Proc Natl Acad Sci USA 2003, 100:6517-6522

15. Dougherty EJ, Pollenz RS: Analysis of Ah receptor-ARNT and Ah receptor-ARNT2 complexes in vitro and in cell culture. Toxicol Sci 2008, 103:191-206

16. Hirose K, Morita M, Ema M, Mimura J, Hamada H, Fujii H, Saijo $Y$, Gotoh O, Sogawa K, Fujii-Kuriyama Y: cDNA cloning and tissuespecific expression of a novel basic helix-loop-helix/PAS factor (Arnt2) with close sequence similarity to the aryl hydrocarbon receptor nuclear translocator (Arnt). Mol Cell Biol 1996, 16:1706-1713

17. Lin BC, Sullivan R, Lee Y, Moran S, Glover E, Bradfield CA Deletion of the aryl hydrocarbon receptor-associated protein 9 leads to cardiac malformation and embryonic lethality. J Biol Chem 2007, 282:35924-35932
18. Lin BC, Nguyen LP, Walisser JA, Bradfield CA: A hypomorphic allele of aryl hydrocarbon receptor-associated protein-9 produces a phenocopy of the AHR-null mouse. Mol Pharmacol 2008, 74:1367-1371

19. Stanford WL, Cohn JB, Cordes SP: Gene-trap mutagenesis: past, present and beyond. Nat Rev Genet 2001, 2:756-768

20. Lee H, Douglas-Jones AG, Morgan JM, Jasani B: The effect of fixation and processing on the sensitivity of oestrogen receptor assay by immunohistochemistry in breast carcinoma. J Clin Pathol 2002, 55:236-238

21. Canzian F, Salovaara R, Hemminki A, Kristo P, Chadwick RB, Aaltonen LA, de la Chapelle A: Semiautomated assessment of loss of heterozygosity and replication error in tumors. Cancer Res 1996, 56:3331-3337

22. Pastinen T, Sladek R, Gurd S, Sammak A, Ge B, Lepage P, Lavergne K, Villeneuve A, Gaudin T, Brandstrom H, Beck A, Verner A, Kingsley J, Harmsen E, Labuda D, Morgan K, Vohl MC, Naumova AK, Sinnett D, Hudson TJ: A survey of genetic and epigenetic variation affecting human gene expression. Physiol Genomics 2004, 16:184-193

23. Seuntiens E, Hauspie A, Roudbaraki M, Vankelecom H, Denef C: Combined expression of different hormone genes in single cells of normal rat and mouse pituitary. Arch Physiol Biochem 2002, 110:12-15

24. Nakayama K, Ishida N, Shirane M, Inomata A, Inoue T, Shishido N, Horii I, Loh DY, Nakayama K: Mice lacking p27(Kip1) display increased body size, multiple organ hyperplasia, retinal dysplasia, and pituitary tumors. Cell 1996, 85:707-720

25. Crabtree JS, Scacheri PC, Ward JM, Garrett-Beal L, Emmert-Buck MR, Edgemon KA, Lorang D, Libutti SK, Chandrasekharappa SC, Marx SJ, Spiegel AM, Collins FS: A mouse model of multiple endocrine neoplasia, type 1, develops multiple endocrine tumors. Proc Natl Acad Sci USA 2001, 98:1118-1123

26. Yin Z, Williams-Simons L, Parlow AF, Asa S, Kirschner LS: Pituitaryspecific knockout of the Carney complex gene Prkar1a leads to pituitary tumorigenesis. Mol Endocrinol 2008, 22:380-387

27. Clemmons DR, Dehoff M, McCusker R, Elgin R, Busby W: The role of insulin-like growth factor I in the regulation of growth. J Anim Sci 1987, 65:168-179

28. Strachan T, Read AP: Creating Disease Models using Gene Transfer Human Molecular Genetics 3. Edited by Strachan T, Read AP. New York, Garland Science, 2004, pp. 575-605

29. Knosp E, Kitz K, Perneczky A: Proliferation activity in pituitary adenomas: measurement by monoclonal antibody Ki-67. Neurosurgery 1989, 25:927-930

30. Mastronardi L, Guiducci A, Spera C, Puzzilli F, Liberati F, Maira G: $\mathrm{Ki}-67$ labelling index and invasiveness among anterior pituitary adenomas: analysis of 103 cases using the MIB-1 monoclonal antibody. J Clin Pathol 1999, 52:107-111

31. Jaffrain-Rea ML, Di Stefano D, Minniti G, Esposito V, Bultrini A, Ferretti E, Santoro A, Faticanti Scucchi L, Gulino A, Cantore G: A critical reappraisal of MIB-1 labelling index significance in a large series of pituitary tumours: secreting versus non-secreting adenomas. Endocr Relat Cancer 2002, 9:103-113

32. Pereira-Lima JF, Marroni CP, Pizarro CB, Barbosa-Coutinho LM, Ferreira NP, Oliveira MC: Immunohistochemical detection of estrogen receptor alpha in pituitary adenomas and its correlation with cellular replication. Neuroendocrinology 2004, 79:119-124

33. Nakao H, Koga M, Arao M, Nakao M, Sato B, Kishimoto S, Saitoh Y Arita N, Mori S: Enzyme-immunoassay for estrogen receptors in human pituitary adenomas. Acta Endocrinol 1989, 120:233-238

34. Zafar M, Ezzat S, Ramyar L, Pan N, Smyth HS, Asa SL: Cell-specific expression of estrogen receptor in the human pituitary and its adenomas. J Clin Endocrinol Metab 1995, 80:3621-3627

35. Yoshida D, Kim K, Yamazaki M, Teramoto A: Expression of hypoxiainducible factor 1alpha and cathepsin $D$ in pituitary adenomas. Endocr Pathol 2005, 16:123-131

36. Harris AL: Hypoxia-a key regulatory factor in tumour growth. Nat Rev Cancer 2002, 2:38-47

37. Graeber TG, Osmanian C, Jacks T, Housman DE, Koch CJ, Lowe SW, Giaccia AJ: Hypoxia-mediated selection of cells with diminished apoptotic potential in solid tumours. Nature 1996, 379:88-91

38. Maltepe E, Keith B, Arsham AM, Brorson JR, Simon MC: The role of ARNT2 in tumor angiogenesis and the neural response to hypoxia. Biochem Biophys Res Commun 2000, 273:231-238 